\title{
Scalanie i percepcja wizualna. Kognitywne warunki odbioru dzieł sztuki (malarstwo, rzeźba, literatura)
}

\begin{abstract}
Saja Krystian, Scalanie i percepcja wizualna. Kognitywne warunki odbioru dzieł sztuki (malarstwo, rzeźba, literatura) [Merging and visual perception. Cognitive conditions for the reception of works of art (painting, sculpture, literature)]. „Przestrzenie Teorii” 13. Poznań 2019, Adam Mickiewicz University Press, pp. 227-246. ISSN 1644-6763. DOI 10.14746/pt.2019.31.12.

This article aims to indicate universal cognitive diagrams for the process of interpreting and creating works of art. This text deals primarily with issues such as visual perception, neural representations and mental maps. Each of these concepts has a direct connection with the reception of works of art (painting, sculptural and literary). A certain scope of cognitive processes may constitute a cognitive universe with respect to works of visual art. In every field of art, a set of similar, if not identical patterns with regard to a specific realization is noticed. We can therefore speak of generalizations, mutations and emanations in culture. This article is only a research proposal, which requires a wider study.
\end{abstract}

KEYWORDS: reception of art, cognitive science, visual perception, literary theory

Od zarania dziejów poznajemy świat dzięki systemowi kognitywnego przetwarzania informacji. Niewykluczone, że już Homo erectus, hominid sprzed półtora miliona lat potrafił opisać rzeczywistość za pomocą symboli. Zdaniem niektórych badaczy mógł on jako pierwszy posługiwać się mowa, choć, jeśli to prawda, czynił to dopiero 400 tysięcy lat temu ${ }^{1}$. Pełną zdolność mówienia i abstrakcyjnego myślenia miał archaiczny Homo sapiens około 200 tysięcy lat temu ${ }^{2}$. Przypuszczalnie język powstał jako system reistycznego odwzorowania rzeczywistości (podobny do zwierzęcego). Następnie, po przekroczeniu progu symbolizacji, czy też, mówiąc precyzyjniej, progu metaforyzacji, stał się on systemem wobec tej rzeczywistości alternatywnym oraz komplementarnym, zdolnym do opisywania przestrzeni men-

${ }^{1}$ Zob. M. Kuckenburg, Pierwsze słowo. Narodziny mowy i pisma, przeł. B. Nowacki, Warszawa 2006, s. 68. To temu gatunkowi przypisuje się wynalezienie ognia, a także wielu narzędzi (zob. S. Kufel, Wrowadzenie do literaturoznawstwa kognitywnego, Zielona Góra 2011, s. 43).

${ }^{2}$ Dowodów dostarczają między innymi wykopaliska archeologiczne i odnalezione w ten sposób artefakty, wśród których istotną rolę odgrywa grawerowana kość ze stanowiska Pech de l'Azé we Francji (zob. S. Kufel, dz. cyt., s. 59). 
talnej ${ }^{3}$. Rewolucja paleolityczna i neolityczna około 30 tysięcy lat temu doprowadziła do wykształcenia się pełnej zdolności odróżniania tego, co „realne”, od tego, co „wyobrażone”. Od tej pory była to egzystencja całkowicie uświadomiona. Przypuszczalnie to wówczas mógł się pojawić archetyp kobiety opiekunki, rodzicielki oraz matki. Wśród hominidów dostrzegamy swoistego rodzaju kult kobiet. Odkryto między innymi figurki tak zwanej Wenus Paleolitycznej oraz Pani Dzikiej Zwierzyny. Niektórzy badacze twierdzą że kształt jaskiń, odwzorowując geometrię trójkąta, nawiązywał do kobiecego łona ${ }^{4}$. Wejście do jaskini mogło być interpretowane jako powrót do łona matki. Prawdopodobnie od tego momentu człowiek zaczął symbolicznie, a następnie w pełni abstrakcyjnie interpretować świat za sprawą kompletnie ukształtowanego systemu kognitywnego. Był to zapewne moment narodzin prehistorycznej sztuki. W jej tworzeniu, oprócz czysto automatycznej reakcji mózgu typu: określone wyjścia reagują na określone wejścia, dużą rolę odegrała (i nadal odgrywa) abstrakcyjna oraz ucieleśniona interpretacja, związana z lewopółkulowymi procesami świadomościowymi. Prawa półkula mózgu traktuje wszystko dosłownie, kodując konkretne obrazy, podczas gdy lewa, wykorzystując dostępne informacje, dookreśla je, zadowalając się pierwszym sensownym wyjaśnieniem ${ }^{5}$. Lewopółkulowe procesy dopowiadania treści nazywamy interpretatorem ${ }^{6}$. Należy pamiętać, że czynności oparte na uświadamianiu sobie czegoś sa powolne, podobnie jak to, co nazywamy świadomym podejmowaniem decyzji ${ }^{7}$ Michael Gazzaniga opisuje je następującymi słowami:

Kiedy idę przed siebie, informacje czuciowe odbierane przez system wzrokowy i słuchowy docierają do wzgórza, które jest swego rodzaju stacją przekaźnikową. Następnie impulsy te są przesyłane do korowych ośrodków przetwarzania i przekazywania do kory czołowej. Tam zostaja zintegrowane z innymi, wyższymi procesami psychicznymi i włączone do strumienia świadomości - to wtedy je sobie uświadamiam ${ }^{8}$.

Pamięć podsuwa nam informacje na temat obiektu zaobserwowanego, co w konsekwencji inicjuje określone działanie. Jest ono poprzedzone

${ }^{3}$ S. Kufel, dz. cyt., s. 54. Myślenie reistyczne „to przetwarzanie impulsowe elementów rzeczywistości tak, by odnieść je do innych elementów rzeczywistości bez wartości naddanej, to znaczy bez naddanej informacji” (tamże, s. 44). Zob. również: M. Johnson, G. Lakoff, Metafora w naszym życiu, przeł. T. Krzeszowski, Warszawa 2011.

${ }^{4}$ Zob. A. Szyjewski, Etnologia religii, Kraków 2001, s. 212-236.

${ }^{5}$ Por. M.S. Gazzaniga, Kto tu rzqdzi - ja czy mój mózg?, przeł. A. Nowak, Sopot 2013, s. $71-80$.

${ }^{6}$ Tamże, s. 75.

7 Tamże, s. 69.

${ }^{8}$ Tamże, s. 70. 
szybkim procesem obliczeniowym zachodzacym w mózgu (trwa to z reguły od jednej do dwóch sekund) oraz przekazaniem informacji sterującej do ośrodków wykonawczych, na przykład do mięśni ${ }^{9}$. W konsekwencji powyższego może nastapić zbyt późna reakcja organizmu na dany bodziec. Ponadto procesy świadome są kosztowne, ponieważ wymagają nie tylko sporo czasu, ale też mnóstwo zasobów pamięci ${ }^{10}$. To dlatego czynności związane z pracą twórczą bywają bardzo skomplikowane oraz żmudne. Sa to oczywiście działania wyższego rzędu. Nie chodzi tu o predyspozycje oraz zdolności autora, lecz o jego naturalne biologiczne ograniczenia, związane z procesem przetwarzania danych w systemie kognitywnym. Człowiek jest przecież skomplikowana, „naturalna” biologiczną maszyna, która, jak każda inna maszyna „sztuczna” z jednostką centralną, może się przegrzać, zawiesić lub ulec uszkodzeniu ${ }^{11}$. Istotna staje się również metafora umysłu jako maszyny. Uważa się, że:

umysł to komputer o konstrukcji biologicznej, który działa przy użyciu programów zasadniczo takich samych jak te, które stosuje się we współczesnych komputerach. Może pobierać od ciała dane i mu ich dostarczać, istnieje też czysto umysłowa sfera manipulacji symbolami, którą opisać można w kategoriach algorytmów, jakich używa się w programach komputerowych ${ }^{12}$.

Problem w tym, że jest to pogląd nadmiernie uproszczony. Bezcielesność algorytmów nie jest do końca możliwa, ponieważ kształtują się one na poziomie neuronu oraz operują na jego pamięci. Istnieją natomiast inne systemy, dzięki którym jesteśmy w stanie ograniczyć do minimum obciążenie poznawcze. Zadaniem niniejszego artykułu jest wskazanie uniwersalnych schematów kognitywnych procesów odbioru, interpretacji oraz kreacji dzieł sztuki (malarskich, rzeźbiarskich oraz literackich). Przypuszczalnie jednym z nich jest percepcja wizualna. W wielu publikacjach autorzy, opisując jej poszczególne etapy, posługują się przykładami zaczerpniętymi ze sztuk pięknych, lecz nie odnoszą się one do ogółu tych sztuk. Reprezentacyjną dziedziną jest w nich przede wszystkim malarstwo. Tymczasem percepcja wizualna dotyczy, rzecz jasna, wszystkich dziedzin artystycznych, w tym również literatury. Artykuł jest próbą dokonania uogólnienia wskazanego problemu oraz udowodnienia istnienia wspólnego, kognitywnego mianownika, łączącego co prawda różne realizacje artystyczne, lecz tego samego motywu przewodniego. Będzie to jedynie propozycja badawcza, która wymaga szerszego opracowania.

9 Tamże.

${ }^{10}$ Tamże, s. $71-72$.

${ }^{11}$ Tamże, s. 13.

${ }^{12}$ G. Lakoff, Kobiety, ogień i rzeczy niebezpieczne. Co kategorie mówia nam o umyśle, przeł. M. Buchta, A. Kotarba, A. Skucińska, Kraków 2011, s. 335. 


\section{Pamięć neuronu}

Najważniejszymi elementami układu nerwowego są oczywiście komórki nerwowe w postaci neuronów, które przechwytuja, transportują oraz magazynują informacje. Neuron to przede wszystkim narzędzie szybkiego przekazywania informacji w układzie funkcjonalnym, w którym następuje tak zwany potencjał czynnościowy w momencie jego aktywacji ${ }^{13}$. Stanowi ponadto magazyn wiedzy, ponieważ są na nim kodowane określone reprezentacje. Jest to zgodne z teorią ucieleśnienia. Organizacja komórek nerwowych we wspomniane układy umożliwia sprawną pracę mózgu. Mózgiem jako systemem, w którym zachodzi proces przepływu i przetwarzania informacji, zajmuje się kognitywistyka (cognitive science $)^{14}$. To interdyscyplinarny kompleks badawczy, w którego skład wchodzą takie dyscypliny jak: psychologia poznawcza, filozofia umysłu, psychosemantyka, lingwistyka kognitywna, matematyka, teoria sztucznej inteligencji, neuronauka i wiele innych ${ }^{15}$. Początek tego typu badań wiąże się z klasycznym problemem filozoficznym, mówiącym o rozłamie umysłu i ciała ${ }^{16}$. Dziś mamy pełna świadomość faktu, że umysł i ciało mają ze sobą wiele wspólnego. Nowy pogląd wskazuje, że rozum ma podstawę w ciele: „istnieje dzięki ciału - w grę wchodzi tu zarówno abstrakcyjny twórczy rozum, jak i rozumowanie na temat konkretnych rzeczy" - zauważa George Lakoff ${ }^{17}$. Należy przy tym pamiętać, że umysł nie jest wyłącznie dosłowny (fizykalny). Tego typu podejście zdewaluuje sztukę jako zaplecze dla kognitywnej metaforyzacji świata ${ }^{18}$. Redukcja umysłu do podłoża biologicznego jest tylko częściowa.

Jednym z podstawowych zadań kognitywistyki jest doprowadzenie do integracji danych uzyskanych z wybranych nauk szczegółowych oraz stworzenie spójnej teorii umysłu ${ }^{19}$. Ma ona zapewnić możliwość pełnego symulowania procesów poznawczych za pomoca maszyn, na przykład robotów i komputerów. Dziedziną z zakresu cognitive science, która zajmuje się analizą pracy neuronu, jest neurokognitywistyka. Opiera się ona na opisie zjawisk poznawczych w kategoriach procesów zachodzących „na poziomie wyższym, które mogą zostać wyjaśnione, odwołując się do neu-

${ }^{13}$ Zob. Neurocybernetyka teoretyczna, red. R. Tadeusiewicz, Warszawa 2009, s. 11, 43.

${ }^{14}$ Por. U. Żegleń, Filozofia umystu, Toruń 2007, s. 48.

${ }_{15}$ Tamże, s. 49.

${ }^{16}$ J. Searl, Umyst. Krótkie wprowadzenie, przeł. J. Karłowski, Poznań 2010, s. 25-27, $49-86$.

${ }^{17}$ Por. G. Lakoff, dz. cyt., s. XIII.

18 Tamże, s. IX, XIII.

${ }^{19}$ Zob. J. Woleński, Jaka jest kognitywistyka każdy(?) widzi, [w:] Metodologiczne i teoretyczne problemy kognitywistyki, red. J. Woleński, A. Dą̧rowski, Kraków 2014, s. 22-24. 
ronalnych mechanizmów leżących na niższych poziomach tych zjawisk"20. Dzięki neurokognitywistyce dowiadujemy się, w jaki sposób mózg inicjuje działanie umysłu. Poznajemy również procesy, dzięki którym wytwarzane są pamięciowe, mentalne reprezentacje percypowanych istot, rzeczy lub zjawisk, obserwowanych w rzeczywistości fizykalnej oraz symulowanych w umyśle. Poznanie uniwersum opiera się na wzajemnej koordynacji działań synaps i neuronów, które potrafią tworzyć złożone struktury pamięciowe, na przykład w postaci modułów. Sa one wytwarzane poprzez zorganizowanie komórek nerwowych w sieci lokalne, budujące wyspecjalizowane obwody ${ }^{21}$. Moduły sa struktura plastyczna, podobnie jak pojedyncze neurony $^{22}$. Możliwe jest nieprzerwane tworzenie oraz likwidowanie połączeń między komórkami nerwowymi. Dzięki temu jesteśmy w stanie jednocześnie zapamiętywać, przetwarzać i konstruować nowe informacje. Ponadto dane zawarte w modułach moga ulegać mutacji, przewartościowaniu oraz zmianie $^{23}$. „Sieci neuronowe posiadają wysoką zdolność do samoorganizacji i adaptacji - potrafią przystosować się do wcześniej nieznanych danych wejściowych; innymi słowy, posiadają zdolność do uczenia się" - stwierdza Andrzej Dąbrowski ${ }^{24}$. Neuronauka poszukuje algorytmów, według których dokonują się w mózgu procesy poznawcze ${ }^{25}$. Zbadanie tych naturalnych, biologicznych układów pozostaje otwartym problemem i wielkim wyzwaniem współczesnych neuronaukowców, podobnie jak ustalenie, czym w ogóle jest świadomośćc ${ }^{26}$.

Powyższe zagadnienia mają swój początek w filozoficznej koncepcji ucieleśnionego umysłu ${ }^{27}$. Zakłada ona między innymi badanie umysłu poprzez analizę zmian aktywności mózgu, którym towarzyszą realizowane funkcje poznawcze (neuronauka poznawcza) ${ }^{28}$. Margaret Wilson zaznacza, że praca mózgu, jako nadrzędnego i pierwotnego organu ciała, polega na pełnieniu funkcji systemu kontrolnego nad umysłem. Głównym obszarem rozważań badaczki jest odbiór wrażeń zmysłowych, a w szczególności per-

${ }^{20}$ B. Jaskuła, Percepcja wizualna jako obszar badań neurokognitywnych, [w:] Metodologiczne..., s. 115. Zob. również: P.K. Machamer, L. Darden, C.F. Craver, Thinking about mechanisms, „Philosophy of Science” 2000, t. 67, nr 1, s. 1-25.

${ }^{21}$ M.S. Gazzaniga, dz. cyt., s. 35.

${ }^{22}$ M. Spitzer, Jak uczy się mózg?, przeł. M. Guzowska-Dąbrowska, Warszawa 2007, s. 79.

${ }^{23}$ Tamże, s. 87.

${ }^{24}$ A. Dąbrowski, Od komputacjonizmu do ucieleśnionego modelu poznania i umystu w kognitywistyce, [w:] Metodologiczne..., s. 62.

${ }^{25}$ Tamże, s. 47.

${ }^{26}$ Tamże, s. 48.

${ }^{27}$ Zob. M. Wilson, Six views of embodied cognition, „Psychonomic Bulletin \& Review” 2002, 9 (4), s. $625-636$.

${ }^{28}$ B. Jaskuła, dz. cyt., s. 116. 
cepcja wzrokowa. W momencie nakierowania badań eksperymentalnych na powyższe zagadnienie pojawił się problem braku możliwości bezpośrednich analiz psychiki innych ludzi. Każdy z nas ma dostęp jedynie do zawartości psychicznej własnego umysłu, z jego subiektywnym podejściem poznawczym oraz osobistymi reprezentacjami rzeczywistości ${ }^{29}$. Oznacza to, że zarówno twórca, jak i odbiorca określonego dzieła sztuki każdorazowo konstruować będzie jego znaczenie na miarę swoich możliwości mentalnych. Każdy czynić to będzie w sposób indywidualny oraz niepowtarzalny ${ }^{30}$. Czy wobec tego jesteśmy skazani na ciagły subiektywizm? Psychologia poznawcza wyjaśniła ów problem. Jej przedstawiciele ustalili, że istnieją pewne uniwersalne procesy, które umożliwiaja generalizację postawy odbiorczej, wpływając na wyniki analiz. Sa to trwałe oraz powtarzające się schematy/wzorce aktywacji sieci neuronalnej ${ }^{31}$. Do tego typu procesów zaliczamy między innymi percepcję wzrokowa. Ma ona zastosowanie w odbiorze wszelkich dzieł sztuki wizualnej, do których, za sprawą obserwowalnej, „żywej” tkanki tekstowej w postaci liczb i liter, zaliczamy również literaturę. Pewne jest, że kognitywny proces interpretacji danych oraz integrowania poszczególnych informacji, oparty na pracy neuronu, stanowi uniwersalium percepcji każdego typu. Procesy te sa określone (a czasem nie) przez specyficzne algorytmy ${ }^{32}$. Ludzki umysł działa schematycznie nie tylko w czasie odbioru, ale i w momencie kreacji określonego dzieła z różnych rodzajów sztuk. Algorytmy stanowić mogą nieświadomą drogę na skróty. Prowadzi ona przez ciało migdałowate, które znajduje się pod wzgórzem i wychwytuje wszystko, co przez nie przepływa ${ }^{33}$. Jest ono bardzo przydatne w momencie zagrożenia. Gdy ciało migdałowate rozpozna wzór, który w przeszłości wiązał się na przykład z niebezpieczeństwem, natychmiast wysyła impuls bezpośrednio

${ }^{29}$ Możemy posługiwać się tak zwanymi stanami intencjonalnymi, przypuszczając $\mathrm{w}$ ten sposób, co sądzą inni, lecz jest to proces niedoskonały i naznaczony sporym marginesem błędu. Istnieje kilka poziomów intencjonalności. Człowiek potrafi posługiwać się sprawnie intencjonalnością do piątego rzędu (zob. R. Dunbar, Nowa historia ewolucji człowieka, przeł. B. Kucharzyk, Kraków 2014, s. 65-66).

${ }^{30}$ Współczesne podejście literaturoznawcze zakłada pełną swobodę interpretacyjna, co wydaje się doskonale komponować z powyższymi tezami. Mówi się między innymi o śmierci autora oraz zakłada się istnienie tylu dzieł literackich, ilu jest odbiorców (zob. R. Barthes, Śmierć autora, „Teksty Drugie: teoria literatury, krytyka, interpretacja” 1999, nr 1/2 (54/55), s. 247-251).

${ }^{31}$ B. Lewandowska-Tomaszczyk, Konstruowanie znaczeń i teoria stapiania, [w:] Kognitywizm w poetyce $i$ stylistyce, red. G. Habrajska, J. Ślósarska, Kraków 2006, s. 8.

${ }^{32} \mathrm{P}$. Tomalski, Cognitive neuroscience: nic nie jest już proste. Kilka uwag o badaniach interakcji ciała i umystu, [w:] Kognitywistyka. O umyśle umyślnie i nieumyślnie, red. J. Szymanik, M. Zajenkowski, Warszawa 2004, s. 159.

${ }^{33}$ M. Gazzaniga, dz. cyt., s. 70. 
do pnia mózgu, a ten inicjuje określoną reakcję ${ }^{34}$. Algorytmom sporo uwagi poświęca dynamicznie rozwijająca się dyscyplina, nazywana neuronauką komputacyjna ${ }^{35}$. Dowodzi ona, że informacje w mózgu są przetwarzane algorytmicznie oraz poszukuje przynależnych im połączeń neuronalnych. Nie ma wątpliwości, że mózgowe sekwencje postępowania są znacznie bardziej skomplikowane niż te stosowane w programach komputerowych, przez co ich prześledzenie oraz zbadanie sprawia wiele problemów ${ }^{36}$. Podobne algorytmy z cała pewnością uczestniczą w interpretacji dzieł sztuki oraz, co istotniejsze, podczas ich formowania. W realizmie obliczeniowym wskazuje się, że każdy proces poznawczy jest z natury algorytmiczny; innymi słowy, myśl może być traktowana wyłącznie jako kwestia manipulacji symbola$\mathrm{mi}^{37}$. Mamy przecież zasób pamięci w postaci reprezentacji, do których się odwołujemy. Stanowią one rozpoznawalne wzorce, dające możliwość automatyzacji przynajmniej niektórych procesów twórczych.

\section{Wokół amalgamatów i teorii reprezentacji}

Podstawowym oraz uniwersalnym modelem percepcji wydaje się scalanie lub, innymi słowy, ,stapianie” zawartości przestrzeni mentalnych w celu wytwarzania nowych jakości ${ }^{38}$. Podstawy tak zwanej teorii stapiania, czy też teorii amalgamatów (blending theory) opracowano w językoznawstwie kognitywnym. Wywodzi się ona z teorii Gilles'a Fauconniera ${ }^{39}$. Zgodnie $\mathrm{z}$ jego koncepcja przestrzenie mentalne (mental spaces) ,zawierają częściową reprezentację scenariusza zdarzeń i odnoszą się zarówno do kodów werbalnych, jak i do innych kodów semiotycznych, takich jak: malarstwo, rzeźba, architektura, taniec, rytuał magiczny" ${ }^{40}$. Przestrzenie mentalne sa zatem uniwersalium nie tylko w sztuce, lecz także dla pozostałych wartości szeroko pojętej kultury. Ich zbiory tworzą tak zwane sieci integracji konceptualnej. To w nich funkcjonuja struktury stopione (amalgama-

${ }^{34}$ Tamże, s. 70.

${ }^{35}$ Zob. T. Sejnowski, C. Koch, P.S. Churchland, Computational neuroscience, „Science”, New Series 1988, vol. 241, no. 4871. (Sep. 9), s. 1299-1306.

${ }^{36}$ U. Żegleń, dz. cyt., s. 48.

${ }^{37}$ Por. G. Lakoff, dz. cyt., s. 336.

${ }^{38}$ B. Lewandowska-Tomaszczyk, dz. cyt., s. 9. Zob. również: S. Coulson, Semantic Leaps: Frame-Shifting and Conceptual Blending in Meaning Construction, Cambridge 2000.

${ }^{39}$ G. Fauconnier, M. Torner, Tworzenie amalgamatów jako jeden $z$ głównych procesów w gramatyce, [w:] Językoznawstwo kognitywne II: Zjawiska pragmatyczne, red. W. Kubiński, D. Stanulewicz, Gdańsk 1996, s. 173-211.

${ }^{40}$ Zob. B. Lewandowska-Tomaszczyk, dz. cyt., s. 10. Zob. również: E. Sweetser, Blended spaces and performativity, „Cognitive Linguistics” 2000, 11-3/4, s. 305-333. 
ty), które powstają z istniejących w sieci przestrzeni wejściowych (input spaces). Zawierają one informacje z poszczególnych domen kognitywnych, czyli przestrzeni generycznych (generic spaces). Stapianie prowadzi do wytwarzania nowych jakości, zaś dalszy proces, tak zwanego przeskoku semantycznego (semantic leap), pozwala na wytworzenie lub zrozumienie tak pojętych nowych struktur mentalnych ${ }^{41}$.

Powyższe założenia możemy uogólnić do całego kognitywnego poznania, przenosząc je na grunt zachowania się neuronów. Będziemy wówczas mówić o takich zagadnieniach jak reprezentacje neuronalne, odpowiedniki przestrzeni wejściowych, które ulegają stapianiu (scalaniu), tworząc nowe jakości - przedmioty mentalne, analogiczne do struktur stopionych (amalgamatów). Reprezentacje, jak również ich nowe jakości, powstają w tak zwanych mapach mentalnych, odpowiednikach sieci integracji konceptualnej ${ }^{42}$. O kognitywnym scalaniu informacji mówimy również w neurokognitywistyce. Opisywany jest w niej proces konstytuowania się „Ja” osobistego w systemie wzgórzowo-korowym mózgu ${ }^{43}$. Rodolfo Llinása stwierdza:

System wzgórzowo-korowy przypomina izochroniczną sferę, w której sensoryczne właściwości świata zewnętrznego w sposób zsynchronizowany są wiązane z wygenerowanymi wewnętrznie motywacjami i wspomnieniami. To czasowo koherentne zdarzenie scala - w czasie - fragmentaryczne składniki zewnętrznej i wewnętrznej rzeczywistości w jeden konstrukt, który nazywamy „jaźnią”. Jest to praktyczny i niezwykle efektywny „wynalazek”: mózgu. Scala się, więc jestem! Koherencja czasowa nie tylko generuje jaźń jako złożony, spostrzegany jako jedność konstrukt, ale również wytwarza pojedyncze centrum, które w skoordynowany sposób realizuje predykcyjne funkcje mózgu - mające kluczowe znaczenie dla przetrwania organizmu. Subiektywność lub jaźń jest więc wytworem dialogu między wzgórzem a kora, albo inaczej mówiąc: zdarzenia scalające składają się na substrat jaźni ${ }^{44}$.

Reprezentacje to trwałe ślady w naszych umysłach po ulotnych wrażeniach $\mathrm{z}$ otaczającego nas świata ${ }^{45}$. To wewnętrzne kopie określonych cech charakterystycznych i struktur otoczenia, przekazywanych z zewnątrz $\mathrm{w}$ formie bodźców ${ }^{46}$. Są one zapisywane na neuronie lub grupie neuronów, zgromadzonych $\mathrm{w}$ modułach ${ }^{47}$. Oznacza to, że wyniki interakcji naszego

${ }^{41}$ Zob. S. Coulson, dz. cyt.

${ }^{42}$ Zob. K. Saja, Wampir w świecie antropii. Kognitywizm subsymboliczny w literaturoznawstwie, Kraków 2017.

${ }^{43}$ Zob. R. Llinás, Ja z wiru, [w:] Formy aktywności umystu. Ujęcie kognitywistyczne, t. 1: Emocje, percepcja, świadomość, red. A. Klawiter, przeł. A. Binder, M. Binder, Warszawa 2008, s. 364-384.

${ }^{44}$ Tamże, s. 379-380.

${ }^{45}$ M. Spitzer, dz. cyt., s. 22.

${ }^{46}$ Tamże, s. 69.

${ }^{47}$ Tamże, s. 79. 
ciała ze środowiskiem, stanowiącym, rzecz jasna, źródło danych percepcyjnych, są magazynowane w określonych „systemach pamięciowych” między innymi poprzez reprezentacje neuronalne. Sa one zgrupowane w struktury bardziej złożone, nazywane mapami mentalnymi. Pełnią one funkcję zbioru reprezentacji danej jednostki ${ }^{48}$. W powyższym rozumieniu mapy nie sa jedynie elementami siatek służących ustaleniu lokacji jednostki w jej najbliższym otoczeniu, lecz są traktowane jako zbiór wszystkich danych (informacji) i wyobrażeń percepcyjnych, powiązanych takowymi siatkami. Poprzez mapowanie umysł „scala” obrazy do formy pełnej, trójwymiarowej reprezentacji. Obiektywna doktryna poznania wskazuje, że:

myślenie to manipulowanie abstrakcyjnymi symbolami. Symbole nabywają znaczenia dzięki temu, że zachodzi odpowiedniość pomiędzy nimi a bytami i kategoriami występującymi w świecie. Dzięki temu umysł może tworzyć obrazy rzeczywistości zewnętrznej, co można określić mianem „odzwierciedlania natury”. [...] Taka wizja poznania ma charakter obiektywistyczny, ponieważ nie bierze pod uwagę natury istot, które poznania dokonuja. [...] umysł może zdobyć prawdziwą wiedzę o świecie zewnętrznym tylko jeśli potrafi odtworzyć (czyli „od-tworzyć”, stworzyć ponownie) to, co rzeczywiście istnieje w świecie ${ }^{49}$.

Problem w tym, że każda $\mathrm{z}$ istot poznających każdorazowo dokonuje mutacji wzorca, niejako na własną rękę, a świat jest bardziej skomplikowany niż nam się wydaje.

Koncepcję map mentalnych zaproponował jako pierwszy Edward Tolman w 1948 roku. Jego zdaniem mapy to typ reprezentacji mentalnej (cykl przemian psychologicznych) w postaci zbioru wyobrażeń przestrzennych danej jednostki. Służą one kodowaniu oraz dekodowaniu informacji o lokalizacji, a także o względnych atrybutach zjawisk w ich codziennym środowisku przestrzennym lub metaforycznym ${ }^{50}$. Sa wykorzystywane do budowy i kumulacji wiedzy o otoczeniu, co pozwala człowiekowi dokonywać wizualizacji obrazów (wytwarzamy wewnętrzną projekcję rzeczywistości). Ponadto dzięki mapowaniu unikamy powielania błędów na przykład w zakresie nieprawidłowej interpretacji zdarzeń. Zmniejsza się w ten sposób obciążenie poznawcze za sprawą uzyskania trwałych i reprezentacyjnych połączeń, co skutkuje wsparciem umysłu w nabywaniu nowych informacji ${ }^{51}$. Rozpatrywanie map w kategoriach czysto lokacyjnych punktów odniesienia wydaje się krzywdzącym uszczupleniem możliwości ludzkiego umysłu. Należy

${ }^{48}$ Zob. K. Saja, Wampir w świecie antropii..., s. 41-52.

${ }^{49}$ G. Lakoff, dz. cyt., s. 159.

${ }^{50}$ E.C. Tolman, Cognitive maps in rats and men, „Psychological Review” 1948, nr 55 (4), s. 189-208.

${ }^{51}$ R.M. Kitchin, Cognitive maps. What are they and why study them?, „Journal of Environmental Psychology" 1994, nr 14 (1), s. 1-19. 
bardziej stanowczo podkreślać, że obok reprezentacji lokacyjnych zawierają one również wiedzę o atrybutach określonych zjawisk, tak jak chciał tego Tolman. Pamiętajmy również, że do dziś pojęcie map mentalnych pozostaje niesprecyzowane, co daje możliwość modyfikacji w obrębie ich znaczenia ${ }^{52}$.

Wydaje się pewne, że w mapach następuje proces scalania istniejących już reprezentacji do nowej jakości pod wpływem procesu twórczego. Stale nadpisujemy ich zawartość, tworząc nowe obrazowania obok starych, już istniejących ${ }^{53}$. W teorii stapiania/scalania mówimy o budowaniu znaczeń oraz nowych obiektów rzeczywistości wewnętrznej poprzez integrację danych wejściowych. W ten sposób tworzymy nowe znaczenia oraz oryginalne figury mentalne. Scalamy wszystko to, co jest zawartością naszych map mentalnych, a zawierają one między innymi:

1) elementy struktur wejściowych, czyli gotowe reprezentacje rzeczywistości, ucieleśnione na neuronie;

2) na bieżąco percypowane jakości;

3) nowe struktury emergentne, powstałe w akcie bieżącej kreacji (amalgamaty/przedmioty mentalne $)^{54}$.

W mapach następuje tak zwane stapianie pojęciowe, czyli operacje doprowadzające do łączenia dynamicznych modeli kognitywnych w sieci wzajemnych relacji przestrzeni mentalnych. Tak budowane znaczenie, wygląd jakiejś postaci, osoby lub przedmiotu dopiero się wyłania ${ }^{55}$. Budując rzeczywistość wewnętrzna, możemy korzystać z dwóch alternatywnych możliwości:

1) tworzyć znaczenia i przedmioty konwencjonalne;

2) tworzyć znaczenia i przedmioty niekonwencjonalne.

Konwencjonalne będą takie wytwory, w trakcie scalania których umysł powiela utrwalone schematy pewnych stałych wzorców aktywacji sieci neuronalnych. Sa to obrazowania, które ulegaja jedynie niewielkiej mutacji lub też ta w ogóle nie następuje (na przykład kreacja postaci ludzkich w kulturze: literaturze, malarstwie, rzeźbie, oparta na stałych schematach prototypowych ${ }^{56}$. Innymi słowy: są to wierne kopie prototypów przedmiotów, zjawisk bądź osób lub też zbudowane na bazie takich matryc nowe jakości, lecz tylko takie, które odwołują się do oryginału. Pamiętajmy, że wszelkiego rodzaju kategorie (stare i nowe) są reprezentowane w umyśle poprzez prototypy, czyli najlepsze przykłady ${ }^{57}$. Trwałe wzorce aktywacji rozumiemy jako wielokrotnie występujące, powtarzane i kopiowane schematy połączeń neu-

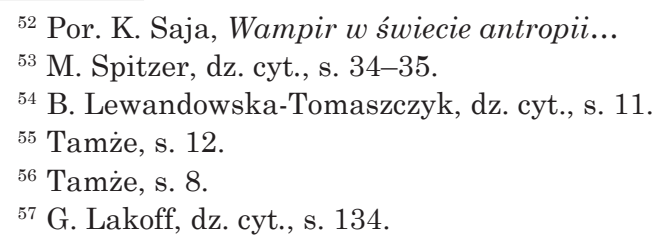


ronalnych w obrębie reprezentacji, rozlokowanych na mapach mentalnych. Mózg korzysta wówczas z wielu skrótów oraz uproszczeń, minimalizując wysiłek poznawczy ${ }^{58}$. W modelowaniu niekonwencjonalnym umysł poszukuje nowych, nieutartych szlaków połączeń, nieraz jedynie pośrednio powiązanych z bodźcem czy zjawiskiem wyjściowym (na przykład w kreacji postaci nadprzyrodzonych, nieposiadajacych dotychczas swoich reprezentacji. Dotyczy to wszystkich rodzajów sztuk) ${ }^{59}$. Ten charakter ludzkiego poznania jest najbardziej interesujący. Świadczy o błędzie założenia o obiektywnym i w pełni referencyjnym istnieniu bytów w umyśle. Świat poprzez subiektywizm poznawczy nie jest trwały oraz niezmienny, lecz ulega ciagłemu przewartościowaniu naszego systemu kognitywnego.

\section{Przedmiot mentalny jako produkt scalania reprezentacji neuronalnej}

Integrując ze sobą dane z reprezentacji neuronalnych (ślady pamięciowe), tworzymy nowe znaczenie bądź figurę w rzeczywistości mentalnej, nazywane przedmiotem mentalnym. Pojęcie to, wielokrotnie przytaczane, określił Jerzy Bartmiński, pisząc, że jest to jednostka podlegająca definiowaniu:

w całym bogactwie jego charakterystyki utrwalonej w językowym obrazie świata. [...] Ten przedmiot mentalny jest projekcją a nie odbiciem, niezależnie od tego, że zwykle istnieje możliwość porównania go (i stwierdzenia podobieństw) z przedmiotem rzeczywistym, dostępnym doświadczeniu empirycznemu ${ }^{60}$.

Przedmiot mentalny istnieje jedynie w umyśle człowieka, dopóki nie uzyska swojej realizacji na przykład w postaci rzeźby, obrazu lub elementu świata przedstawionego w utworze literackim. Rozróżniamy jednostki referencyjne względem rzeczywistości fizykalnej, jak również takie, którym nie można przypisać obiektów realnych. Wówczas pozostają one wynikiem projektowania czegoś nowego, lecz z już istniejących reprezentacji. Innymi słowy: przedmiot mentalny to projekcja świata wewnętrznego, subiektywnego uniwersum autora, które może, lecz nie musi mieć referencyjności. Artysta każdorazowo kreuje rzeczywistość poprzez scalanie danych celem stworzenia oryginalnego dzieła sztuki. Postępuje tak również odbiorca

${ }^{58}$ Procesy poznawcze są utrwalone i stają się w pewien sposób zautomatyzowane.

${ }^{59}$ B. Lewandowska-Tomaszczyk, dz. cyt., s. 8.

${ }^{60}$ N. Lemann, Prototyp i profilowanie przedmiotu mentalnego SMOK $w$ literaturze fantasy, na wybranych przykładach, [w:] Kognitywizm..., s. 143-144; J. Bartmiński, Definicja kognitywna jako narzędzie opisu konotacji. [w:] Profilowanie pojęć. Wybór prac, red. J. Bartmiński, Lublin 1993, s. 75-76. 
gotowego już dzieła z powodu wyjątkowej cechy percepcji wizualnej, jaka jest jej schematyczność. Opiera się ona na określonych etapach operacji mentalnych, następujących w trakcie obcowania odbiorcy ze sztuka. We współczesnych badaniach neurokognitywnych sztuki wizualnej używa się jako bodźca emocjonalnego (przede wszystkim malarstwa). Wiadomo bowiem, że określone procesy emocjonalne aktywują daną część mózgu na tak zwanej sieci złożonej (complex network). Jest to abstrakcyjny model, który może być stosowany do reprezentowania struktur mózgu na różnych jego poziomach ${ }^{61}$. Zaletą tego typu teorii jest możliwość kwantyfikacji ich parametrów, co pozwala analizować je zarówno z punktu widzenia topologii, jak i procesów powstawania ${ }^{62}$. Nie od dziś wiadomo, że sztuka to doskonały bodziec dla emocji ${ }^{63}$.

Odczuwana emocja może być czynnikiem integrującym różne elementy doświadczenia oraz funkcjonowania wielu struktur mózgu przez to, że emocja jest energia, która kieruje, organizuje, nasila lub osłabia aktywność poznawczą i jest zarówno doświadczeniem jak i wyrazem tej aktywności ${ }^{64}$.

Emocje wydobyte z dzieł sztuki wzmacniają przekaz wizualny. Bolesław Jaskuła stwierdza: „Zadaniem artysty jest zatem takie spreparowanie wyjściowe bodźca, aby podmiot mógł aktywnie przeżywać jego poznawanie"65. Dzieje się tak na dwóch poziomach: nadawczym, kiedy autor scala, a zatem buduje mentalnie dzieło sztuki, oraz odbiorczym, gdy jest ono poddane analizie i interpretacji. Poziom drugi (analityczno-interpretacyjny) jest najbardziej istotny dla naszych rozważań. Zdaniem Semira Zekiego odbiór sztuki uwarunkowany jest przez prawa rządzące aktywnością mózgu człowieka - tak zwanego mózgu wzrokowego ${ }^{66}$. Procesy zachodzące na poziomie neuronalnym warunkuja percepcję sztuki, co jest w pełni logiczne. Następuje ona w trzech etapach:

1) ekstrahowania fizycznych, ogólnych właściwości obrazu, takich jak linie, kolor, tekstury itp., realizowany w wyniku uaktywniania pierwotnych obszarów funkcjonowania kory mózgowej;

2) ekstrahowania kształtów i realizacji przestrzennych realizowany w wyniku uaktywniania obszarów asocjacyjnych kory mózgowej;

\footnotetext{
${ }^{61}$ B. Jaskuła, dz. cyt., s. 126.

${ }^{62}$ Por. tamże, s. 127. Zob. również: M.E.J. Newman, The structure and function of complex networks, „SIAM Review” 2003, nr 45, s. 167-256.

${ }^{63}$ Zob. M. Budd, Muzyka i emocje. Wybrane teorie filozoficzne, przeł. R. Kasperowicz,

${ }^{64}$ B. Jaskuła, dz. cyt., s. 129

65 Tamże.

${ }^{66}$ Zob. S. Zeki, Inner Vision: An Exploration of Art. And the Brain, Oxford 2000.
} Gdańsk 2014.

\begin{tabular}{l|l} 
Krystian Saja & $\mathbf{2 3 8}$ \\
&
\end{tabular}


3) ustalania znaczenia struktury bodźca wizualnego (określenie obiektów i zachodzących pomiędzy nimi relacji), realizowany w wyniku uaktywniania obszarów transmodalnych ${ }^{67}$.

Różne style aktywizują odrębne szlaki przetwarzania informacji. Wydaje się, że tak rozumiane etapy percepcji stanowią uniwersalny algorytm odbioru sztuki każdego typu. Percypowany obiekt, choć występujący w różnych dziedzinach jednocześnie (na przykład w malarstwie i rzeźbie), będzie kognitywnie odbierany w podobny sposób w każdej z tych dziedzin. Dzieje się to $\mathrm{z}$ uwagi na fakt istnienia pewnego modelu prototypowego, którego elementy sa poszukiwane i wykazane $\mathrm{w}$ każdej z realizacji oraz $\mathrm{w}$ niemal analogiczny sposób. Przykładem może być postać olbrzyma. W pierwszej kolejności określamy jego ogólne cechy (proporcję, kształt, teksturę). Następnie ze zbioru tych cech wyodrębniamy określone elementy uszczegółowienia, to znaczy dookreślamy detale przestrzenne (oczy, uszy, nos, grymas twarzy, chropowatość lub gładkość cery, a także niedostrzegalne w pierwszym etapie, mniej widoczne elementy tła). Istotne są również inne domeny. Uruchamiamy dodatkowe relacje przestrzenne, takie jak rzucany cień, dominacja nad przestrzenia, ogrom domostwa lub jaskini olbrzyma itp. Ostatecznie interpretujemy tak uszczegółowioną postać z dzieła sztuki, sumując wszystkie odnalezione struktury (postać i jej detale z peryferium tła), wyznaczając w ten sposób funkcję danego przedstawienia. Innymi słowy: scalamy wszystkie przestrzenie $\mathrm{w}$ jednolitą wizualizację o określonym znaczeniu. Oczywiście, wskazuje się dziś na istniejąca różnorodność systemów kategorialnych lub zróżnicowanie percepcji (na przykład koloru białego w osądzie ludu zamieszkujacego tereny pokryte wiecznym śniegiem). Należy jednak pamiętać, iż mimo odmienności detalu prototyp w przeważającej części swoich cech pozostaje niezmienny, zaś sposób jego poznania zmysłowego jest analogiczny.

\section{Schematy połączeń i cechy wzorcowe}

Jak się okazuje, obcując z dziełem sztuki, niezależnie od dziedziny, posługujemy się zarówno schematem funkcjonalnym percepcji wizualnej, jak i zestawem uniwersalnych cech, określanych każdorazowo w akcie percepcji. Przytoczmy kilka istotnych prac, w których pojawia się postać olbrzyma. Należą do nich prace malarskie, takie jak chociażby dziewiętnastowieczny Kolos (1808-1812 lub 1818-1825) oraz akwatinta Olbrzym (1818-1825) Francisca Goi lub też współczesny obraz Jacka Sroki o tym

${ }^{67}$ Por. B. Jaskuła, dz. cyt., s. 130-131. 
samym tytule (2013). Kolos, często interpretowany jako symbol hiszpańskiej wojny niepodległościowej i heroicznego oporu Hiszpanów przeciwko siłom napoleońskim w latach 1807-1814, przedstawia nagiego olbrzyma kroczącego dolina, ze wzniesionymi w gniewie pięściami oraz zamkniętymi oczyma. Kontrastuje z nim tłum maleńkich postaci w ciemnej dolinie (ludzi i zwierząt) uciekających w panice przed kolosem. Z kolei obraz Olbrzym przedstawia postać siedzącego na skraju urwiska bądź brzegu morskiego nagiego kolosa, spoglądającego na księżyc ze smutkiem i zaduma. U dołu obrazu, podobnie jak w przypadku poprzedniego dzieła, widnieją najprawdopodobniej miniaturowe domostwa. Pomiędzy obiema pracami istnieje oczywisty dialog wizualny, ale drugi nigdy nie mógłby istnieć bez pierwszego, ponieważ obrazy uzupełniają się wzajemnie ${ }^{68}$. Motywami łączącymi oba przedstawienia jest nagość olbrzymów, czerń, pagórkowate ukształtowanie terenu oraz przede wszystkim ogrom w kontraście z maleńkościa. Z kolei płótno Sroki prezentuje olbrzyma w pozycji siedzącej, tym razem ubranego, chwytającego się za czoło, spoglądając na maleńką postać kobiety w zielonym bikini. Tym razem barwy sa jasne, wręcz rażące. Nie zmieniła się natomiast postawa olbrzyma, a także wyraźnie zarysowany kontrast pomiędzy gigantyzmem a miniaturyzmem postaci. Prototypowymi cechami olbrzymów staje się gigantyzm, postawa ciała oraz kontrast względem przestrzeni.

Podobne schematy przedstawień odkryjemy w dziełach rzeźbiarskich, na przykład w Apenińskim Kolosie autorstwa Giovanniego da Bologna ${ }^{69}$ z XVI wieku lub też współczesnej instalacji olbrzyma wyłaniającego się z podziemnego świata Ervina Lorántha Hervé z Budapesztu (2014). Pierwsza z wymienionych rzeźb przedstawia olbrzyma rodem z ludowych legend, pół-człowieka i pół-górę. Wznosi się on na wysokość niemal jedenastu metrów ponad wioską Villa di Pratolino w Toskanii. Postać człowieka o długiej brodzie podpiera się dłonią na skale oraz wydaje się po niej wspinać, spoglądając $\mathrm{w}$ toń stawu. Z kolei olbrzym wyłaniajacy się z podziemia przedstawia krzyczącego oraz wyraźnie wściekłego kolosa, jedną ręką podpierającego się o grunt, zaś drugą unoszącego w górę warstwę darni. Schematy obu posagów sa analogiczne do tych z przedstawień malarskich. Sa nimi gigantyzm, kontrast względem przestrzeni oraz przyjęta pozycja ciała. Warto również wspomnieć o gigantycznych posagach z Wysp Wielkanocnych, które według najnowszych ustaleń mają olbrzymie ciała zakopane w ziemi, a także o nieistniejącym już Kolosie z wyspy Rodos. Oczywiście w każdym z tych przypadków zasady działania percepcji wizualnej są analogiczne, przy

${ }^{68}$ J. Vega, El Coloso es de Francisco de Goya, Heraldo de Aragón suplement Artes \& Letras, <https://antoncastro.blogia.com/2012/040101-jesusa-vega-nueva-catedratica-escribe-de-el-coloso-y-de-goya.php> [dostęp: 26.05.2019].

${ }^{69}$ Właściwie Jean de Boulogne. 
czym w rzeźbiarstwie naturalnym tłem staje się przyroda bądź elementy architektoniczne.

Nie zapomnijmy również o dziełach literackich, takich jak Odyseja ${ }^{70}$ Homera, w której mamy do czynienia z olbrzymem Polifemem, Gargantua $i$ Pantagruel $^{71}$ François Rabelais'go, gdzie występują dwa tytułowe olbrzymy (ojciec i syn), o Hobbicie, czyli tam $i$ z powrotem ${ }^{72}$ oraz Wtadcy pierścieni ${ }^{73}$ Johna Ronalda Reuela Tolkiena, gdzie znajdziemy opisy wielu górskich kolosów i olbrzymów (podobnych do tych, które przedstawia Goya). Pamiętajmy również o biblijnym Goliacie. To tylko mały odsetek z niezliczonej ilości przedstawień z wszelkiego rodzaju sztuk. Wszędzie, niezależnie od czasu powstania danej pracy, powtarza się pewna schematyczność kształtów, proporcji, postawy ciała oraz monstrualności. Sa to postacie wykreowane na fundamencie tych samych zasad uniwersalnych, wśród których przeważa kontrast względem ludzi, zarówno cielesny, jak i duchowy, jeśli mówić będziemy o postaciach literackich. Ich odbiór cechuje się prototypową schematycznością, gdyż ludzki aparat poznawczy jest zorganizowany w ściśle określony sposób.

W percepcji wizualnej występuje również tak zwane zjawisko dopełniania konceptualnego. Formy, które fizycznie ukazywane są odbiorcy tylko częściowo lub we fragmentach, zostają dopowiedziane ${ }^{74}$. Przykładem mogą być obrazy Jeana Lamberta-Ruckiego, polskiego awangardzisty, który w swoich dziełach świadomie operował efektem dopełniania ${ }^{75}$.

Identyczne zjawiska zachodzą w literaturze. Możemy w prosty sposób sparafrazować poszczególne etapy procesu percepcji wizualnej do formy:

1) odbiór dzieła literackiego przez czytelnika, czyli ekstrahowania ogólnych właściwości przestrzennych książki (do cech ogólnych należy jej rozmiar, kolor, zapach, a także zawarta wewnątrz treść, która nim nastapi interpretacja niewiele lub też zupełnie nic nie znaczy);

2) analiza literaturoznawcza dzieła literackiego, czyli ekstrahowania poszczególnych przestrzeni generycznych książki (fizycznych: odwołujących się do praw fizyki, biologii, chemii oraz mentalnych: osadzonych w przestrzeni religijnej, mitycznej, symbolicznej, archetypowej itd. $)^{76}$;

\footnotetext{
${ }^{70}$ Homer, Odyseja, przeł. L. Siemieński, Wrocław 1981.

${ }^{71}$ F. Rabelais, Gargantua i Pantagruel, przeł. T. Boy-Żeleński, Kraków 2010.

${ }^{72}$ J.R.R. Tolkien, Hobbit, czyli tam i z powrotem, przeł. M. Skibniewska, Warszawa 2011.

${ }^{73}$ Tenże, Władca Pierścieni: Drużyna Pierścienia, przeł. M. Skibniewska, Warszawa 2011.

${ }^{74}$ B. Lewandowska-Tomaszczyk, dz. cyt., s. 17.

${ }^{75}$ Znane dzieła malarskie artysty określonego typu to: La visite (1919), Kompozycja (1919), Femme Et Profil D'homme (1921), Les Promeneurs, (1924), Montmartre (1925).

${ }^{76}$ Zob. S. Kufel, dz. cyt., s. 212.
} 
3) interpretacja dzieła literackiego, czyli ustalania znaczenia struktury opartej na wzajemnej relacji elementów przestrzeni generycznych.

Prawdopodobnie za wskazane czynności odpowiadaja te same obszary kory mózgowej, które uczestniczą w percepcji wizualnej. Obcowanie z dziełem literackim, sformalizowanym do postaci tekstu składającego się z liter i liczb, które sa przecież odbierane wzrokowo, niezaprzeczalnie stanowi rodzaj tej percepcji. Żadnych wątpliwości nie wzbudza natomiast zjawisko dopełniania. Jako odbiorcy - czytelnicy dzieła literackiego - dopowiadamy treści niepełne oraz niewiadome (zgodnie lub rzadziej niezgodnie z intencją autora). Zresztą autor danej książki bardzo często świadomie pozostawia nam luki i niedomówienia. W pełni uświadomionym dopełnianiem posługuje się wielu artystów tak w literaturze, malarstwie, jak i rzeźbie. Zjawisko to występuje w poezji oraz w sztukach muzycznych. Nazywamy je reprezentacją siły rozpędu (representational momentum) ${ }^{77}$. W poezji potrafimy dookreślić rymy w wersie, zaś po usłyszeniu frazy melodycznej jesteśmy $\mathrm{w}$ stanie przewidzieć wręcz narzucająca się formę jej zakończenia ${ }^{78}$. Ten sam efekt występuje w zwykłej rozmowie, gdy domyślamy się dalszej części wypowiedzi rozmówcy, a także w percepcji zdarzeń, na przykład w „przewidywaniu, graniczącym z pewnością, drogi upadającego ze stołu talerza, którą każdy człowiek wizualizuje, zanim jeszcze przedmiot dotknie podłogi" "9. Opisywane dopełnianie stanowi jeden z czterech typów podstawowych operacji mentalnych, mających występować w trakcie łączenia amalgamatów (reprezentacji). Zostały one opisane przez Josepha Grady'ego ${ }^{80}$ oraz Gilles'a Fauconiera i Marka Turnera ${ }^{81}$. Oprócz wspomnianego powyżej zjawiska wyróżniają oni również kompozycje, elaboracje i kompresje.

Proces kompozycji oznacza pewną formę scalania reprezentacji, gdy jedno z pojęć lub relacji z jednej przestrzeni mentalnej łączy się z innym lub przenosi do odmiennej przestrzeni. Tworzy się wówczas nowe znaczenie, odmienne od znaczeń reprezentacji wejściowych. Opis powyższego procesu dotyczy oczywiście przykładów językoznawczych, co nie oznacza, że nie możemy przenieść go wprost na inne dziedziny. Umysł artysty, wytwarzając nową reprezentację, na przykład jakiegoś bytu nadprzyrodzonego, korzysta z gotowych wzorców prototypowych, pochodzących z danych wejściowych, komponując z nich nowe jakości. Reprezentacje wejściowe nie sa przy tym

${ }^{77}$ Zob. J. Freyd, R. Finke, Reprezentational momentum, „Journal of Experimental Psychology: Learning, Memory, and Cognition” 1984, 10, s. 126-132.

${ }^{78}$ Por. B. Lewandowska-Tomaszczyk, dz. cyt., s. 18.

79 Tamże.

${ }^{80} \mathrm{~J}$. Grady, Cognitive mechanisms of conceptual integration, „Cognitive Linguistics” 2000, 11-3/4, s. 355-345.

${ }^{81}$ G. Fauconnier, M. Torner, dz. cyt., s. 283-304. 
pozbawione znaczeń pierwotnych. Innymi słowy: nowe realizacje zachowują powiązanie ze składowymi. Kiedy mówimy o wilkołaku, niezmiennie ważne pozostaja jego dwie reprezentacje wejściowe: człowieka oraz wilka. Pierwotne znaczenia nie są bagatelizowane, a tym bardziej odrzucane. Łaczą się w nowy przedmiot mentalny, o odmiennej definicji, lecz opartej na fundamencie znaczeń jej elementów składowych. Odbywa się to poprzez hybrydyzację lub kontrast tych znaczeń. Podobnie w przypadku olbrzyma: ważna pozostaje zarówno jego referencyjność do człowieka, jak i zestaw odniesień do elementów natury, na przykład ziemi, skał, morza, drzew, gór i lasów, słońca oraz księżyca itp. Olbrzymy bardzo często pozostają silnie powiazane z przyrodą lub też stanowią jej bezpośrednią część. Bywają porośnięte mchem, trawą lub drzewami, ich ciała przypominaja głazy lub strukturę ziemi. Ponadto są one przedstawiane w określonych warunkach środowiskowych. Towarzyszy im wiatr, sztorm, szum lasów i rzek, echo grot skalnych itp. Sa to cechy dopełniające ogólny model prototypu, które wspierają proces kompozycji oraz stanowią jego istotny element.

Proces elaboracji (uszczegółowienia) wiąże się z pogłębieniem i coraz bardziej szczegółowym odwzorowaniem danego elementu w strukturze stopionej oraz z uaktywnianiem dalszych obszarów semantycznych sieci asocjacyjnych z nim związanych ${ }^{82}$. W sporządzanych opisach wilkołaka będziemy obserwować silniejszą obecność cech wilczych po zachodzie słońca oraz ludzkich za dnia. Innymi słowy: odwzorowanie będzie coraz dokładniejsze. Jego wizerunek będzie dosłownie „wypełniony” zestawem ściśle określonych cech. Identycznie wygląda to w przypadku olbrzyma, gdy jego charakterystyka zyskuje pełniejszy wymiar. W literaturze proces ten jest niezwykle znaczący. Pozwala wykreować już nie tylko dokładna charakterystykę zewnętrzną kolosa, ale i stworzyć jego biografię. Przykładem jest postać Polifema, mieszkańca Sycylii, syna Posejdona i nimfy Toosy. Grecki poeta Teokryt wzbogacił ową postać, pisząc około 275 roku dwa poematy. Opisał w nich nieszczesśliwą miłość Polifema do nimfy morskiej Galatei.

Ostatnim procesem jest mechanizm kompresji, czyli swoiste ścieśnianie sieci pojęciowej ${ }^{83}$. Mówimy wówczas o odbiorze holistycznym, zaistniałym w wyniku ostatecznego stapianie cech danego obiektu. Poprzez mechanizm kompresji powstaje uniwersalny i trwały wzór postaci wilkołaka, z zestawem cech niezmiennych, kopiowanych jako informacja wzorcowa. Jest nią charakterystyczna, ulegająca kopiowaniu oraz mutacji cecha, jakość lub zespół cech i jakości, które przyczyniają się do określenia, wyszczególnienia,

\footnotetext{
82 Por. B. Lewandowska-Tomaszczyk, dz. cyt., s. 14.

${ }^{83}$ Tamże.
} 
wyznaczenia oraz nazwania danego wyobrażenia (przedmiotu mentalnego) ${ }^{84}$. Zjawisko kompresji zostało opisane w trakcie rozważań na temat olbrzyma. Mówiliśmy wówczas o uniwersalnym zestawie jego cech w każdym typie dzieł sztuki. Sa to niezmienne, uniwersalne oraz wzorcowe cechy danej postaci - cechy prototypu.

\section{Podsumowanie}

Pewien zakres procesów kognitywnych stanowić może uniwersum poznawcze względem dzieł sztuki wizualnej. W każdej dziedzinie sztuki dostrzegalny jest zestaw podobnych, jeśli nie identycznych schematów, analizowanych oraz stosowanych w odniesieniu do konkretnej realizacji. Możemy zatem mówić o uogólnieniach, mutacjach i emanacjach w kulturze. Co ważne nie ma większego znaczenia ani czas, ani przestrzeń, w jakiej powstawała dana realizacja. System kognitywny jest przecież niezmienny od momentu osiągnięcia przez niego pewnego rodzaju „dojrzałości” ewolucyjnej. Od wieków tak samo spoglądamy w niebo, percypujemy rzeczywistość ziemska, tworzymy referencje rzeczywistości oraz jej iluzje. Świadczą o tym liczne artefakty, które zawierają zestawy cech wzorcowych. Istnieje zatem w kulturze pewien niezmienny zakres "genotypu” (kulturotypu), który warunkuje wierność kopiowania i naśladownictwa prototypów. Nie jest to jednak tematem naszych rozważań. Ważny jest dla nas fakt, że sztuka, jaką znamy niezmiennie czerpie z kodów, będących schematami kognitywnymi, które są zgromadzone w ludzkim umyśle w postaci wzorców danej reprezentacji.

\section{BIBLIOGRAFIA}

Barthes R., Śmierć autora, „Teksty Drugie: teoria literatury, krytyka, interpretacja” 1999, nr 1/2 (54/55), s. 247-251.

Bartmiński J., Definicja kognitywna jako narzędzie opisu konotacji, [w:] Profilowanie pojęć. Wybór prac, red. J. Bartmiński, Lublin 1993, s. 75-76.

Budd M., Muzyka i emocje. Wybrane teorie filozoficzne, przeł. R. Kasperowicz, Gdańsk 2014.

Coulson S., Semantic Leaps: Frame-Shifting and Conceptual Blending in Meaning Construction, Cambridge 2000.

Dąbrowski A., Od komputacjonizmu do ucieleśnionego modelu poznania i umystu w kognitywistyce, [w:] Metodologiczne i teoretyczne problemy kognitywistyki, red. J. Woleński, A. Dąbrowski, Kraków 2014, s. 47-87.

Dunbar R., Nowa historia ewolucji człowieka, przeł. B. Kucharzyk, Kraków 2014.

${ }^{84}$ Por. K. Saja, Od scalania do obrazowania. Informacja wzorcowa jako czynnik modelujacy dzieło literackie (ujęcie kognitywne), „Świat Tekstów. Rocznik Słupski” 2018, nr 16. 
Fauconnier G., Torner M., Compression and global insight, „Cognitive Linguistics” 2000, 11-3/4, s. 283-304.

Formy aktywności umystu. Ujęcie kognitywistyczne, t. 1: Emocje, percepcja, świadomość, red. A. Klawiter, przeł. A. Binder, M. Binder, Warszawa 2008.

Freyd J., Finke R., Reprezentational momentum, „Journal of Experimental Psychology: Learning, Memory, and Cognition” 1984, 10, s. 126-132.

Gazzaniga M.S., Kto tu rzadzi - ja czy mój mózg?, przeł. A. Nowak, Sopot 2013.

Grady J., Cognitive mechanisms of conceptual integration, „Cognitive Linguistics” 2000, $11-3 / 4$, s. 355-345.

Homer, Odyseja, przeł. L. Siemieński, Wrocław 1981.

Jaskuła B., Percepcja wizualna jako obszar badań neurokognitywnych, [w:] Metodologiczne i teoretyczne problemy kognitywistyki, red. J. Woleński, A. Dąbrowski, Kraków 2014, s. 113-141.

Językoznawstwo kognitywne II: Zjawiska pragmatyczne, red. W. Kubiński, D. Stanulewicz, Gdańsk 1996.

Johnson M., Lakoff G., Metafora w naszym życiu, przeł. T. Krzeszowski, Warszawa 2011.

Kitchin R.M., Cognitive maps. What are they and why study them?, „Journal of Environmental Psychology" 1994, nr 14 (1), s. 1-19.

Kognitywistyka. O umyśle umyślnie i nieumyślnie, red. J. Szymanik, M. Zajenkowski, Warszawa 2004.

Kognitywizm w poetyce i stylistyce, red. G. Habrajska, J. Ślósarska, Kraków 2006.

Kuckenburg M., Pierwsze stowo. Narodziny mowy i pisma, przeł. B. Nowacki, Warszawa 2006.

Kufel S., Wprowadzenie do literaturoznawstwa kognitywnego, Zielona Góra 2011.

Lakoff G., Kobiety, ogień i rzeczy niebezpieczne. Co kategorie mówiq nam o umyśle, przeł. M. Buchta, A. Kotarba, A. Skucińska, Kraków 2011.

Lemann N., Prototyp i profilowanie przedmiotu mentalnego SMOK $w$ literaturze fantasy, na wybranych przyktadach, [w:] Kognitywizm w poetyce $i$ stylistyce, red. G. Habrajska, J. Ślósarska, Kraków 2006, s. 143-157.

Lewandowska-Tomaszczyk B., Konstruowanie znaczeń i teoria stapiania, [w:] Kognitywizm w poetyce $i$ stylistyce, red. G. Habrajska, J. Ślósarska, Kraków 2006, s. 7-35.

Llinás R., Ja z wiru, [w:] Formy aktywności umystu. Ujęcie kognitywistyczne, t. 1: Emocje, percepcja, świadomość, red. A. Klawiter, przeł. A. Binder, M. Binder, Warszawa 2008, s. 364-384.

Machamer P.K., Darden L., Craver C.F., Thinking about mechanisms, „Philosophy of Science" 2000, vol. 67, nr 1, s. 1-25.

Metodologiczne i teoretyczne problemy kognitywistyki, red. J. Woleński, A. Dąbrowski, Kraków 2014.

Neurocybernetyka teoretyczna, red. R. Tadeusiewicz, Warszawa 2009.

Newman M.E.J., The structure and function of complex networks, „SIAM Review” 2003, nr 45 , s. $167-256$.

Profilowanie pojęć. Wybór prac, red. J. Bartmiński, Lublin 1993.

Rabelais F., Gargantua i Pantagruel, przeł. T. Boy-Żeleński, Kraków 2010.

Saja K., Od scalania do obrazowania. Informacja wzorcowa jako czynnik modelujacy dzieło literackie (ujęcie kognitywne), „Świat Tekstów. Rocznik Słupski” 2018, nr 16. 
Saja K., Wampir w świecie antropii. Kognitywizm subsymboliczny w literaturoznawstwie, Kraków 2017.

Searl J., Umyst. Krótkie wprowadzenie, przeł. J. Karłowski, Poznań 2010.

Sejnowski T., Koch C., Churchland P.S., Computational neuroscience, „Science”, New Series 1988, vol. 241, nr 4871. (Sep. 9, 1988), s. 1299-1306.

Spitzer M., Jak uczy się mózg?, przeł. M. Guzowska-Dąbrowska, Warszawa 2007.

Sweetser E., Blended spaces and performativity, „Cognitive Linguistics” 2000, 11-3/4, s. 305-333.

Szyjewski A., Etnologia religii, Kraków 2001.

Tolkien J.R.R., Hobbit, czyli tam i z powrotem, przeł. M. Skibniewska, Warszawa 2011.

Tolkien J.R.R., Wtadca Pierścieni: Drużyna Pierścienia, przeł. M. Skibniewska, Warszawa 2011.

Tolman E.C., Cognitive maps in rats and men, „Psychological Review” 1948, nr 55 (4), s. $189-208$.

Tomalski P., Cognitive neuroscience: nic nie jest już proste. Kilka uwag o badaniach interakcji ciała i umystu, [w:] Kognitywistyka. O umyśle umyślnie i nieumyślnie, red. J. Szymanik, M. Zajenkowski, Warszawa 2004, s. 157-176.

Vega J., El Coloso es de Francisco de Goya, Heraldo de Aragón suplement Artes \& Letras, $<$ https://antoncastro.blogia.com/2012/040101-jesusa-vega-nueva-catedratica-escribe-de-el-coloso-y-de-goya.php> [dostęp: 26.05.2019].

Wilson M., Six views of embodied cognition, „Psychonomic Bulletin \& Review” 2002, vol. 9 (4), s. 625-636.

Woleński J., Jaka jest kognitywistyka każdy(?) widzi, [w:] Metodologiczne i teoretyczne problemy kognitywistyki, red. J. Woleński, A. Dąbrowski, Kraków 2014, s. 9-26.

Zeki S., Inner Vision: An Exploration of Art. And the Brain, Oxford 2000.

Żegleń U., Filozofia umystu, Toruń 2007. 